\title{
Potensi glukomanan pada tepung porang sebagai agen anti-obesitas pada tikus dengan induksi diet tinggi lemak
}

The potential of glucomannan derived from konjac flour as an antiobesity agent in rats induced by high fat diet

\author{
Choirun Nissa ${ }^{1}$, Indah Juliana Madjid ${ }^{1}$
}

${ }^{1}$ Program Studi Ilmu Gizi, STIKes Widya Cipta Husada Malang

\begin{abstract}
Background: Epidemiological studies indicate that the global prevalence of obesity has increased. Glucomannan is a water soluble, non-starch polysaccharide, known as soluble fiber. Glucomannan has the ability to lower blood cholesterol levels and blood glucose levels, weight loss and affect the activity of intestinal and immune system function. Objective: The purpose of this study was to determine the effect of glucomannan derived from konjac flour as antiobesity agent on body weight and food intake in rats induced by high-fat diet. Method: Research was conducted in the Pharmacology Laboratory, Faculty of Medicine, University of Brawijaya. This study uses a true experimental research design. Animals were divided into six groups, normal group, normal + konjac flour, obese group, obese group + konjac flour $100 \mathrm{mg} / \mathrm{kg}$ body weight, obese group + konjac flour $200 \mathrm{mg} / \mathrm{kg}$ body weight, obese group + konjac flour $400 \mathrm{mg} / \mathrm{kg}$. Results: Based on One Way Annova test, there is a significant difference (p: 0.000) on body weight after konjac flour treatment in all groups. Based on the Kruskal Wallis test, there is a difference on food intake in various groups $(p=0.000)$. Conclusion: It can be concluded that glucomannan derived from konjac flour can decrease body weight and food intake in rats induced by high-fat diet.
\end{abstract}

KEY WORDS: body weight; food intake; glucomannan; konjac flour; obesity

\begin{abstract}
ABSTRAK
Latar belakang: Studi epidemiologis menunjukkan bahwa prevalensi obesitas global telah mengalami peningkatan. Glukomanan merupakan polisakarida larut air, yang dikenal sebagai serat larut. Glukomanan memiliki kemampuan untuk menurunkan kadar kolesterol darah dan kadar glukosa darah, menurunkan berat badan, dan mempengaruhi aktivitas usus dan fungsi sistem kekebalan tubuh. Tujuan: Penelitian ini bertujuan untuk mengetahui pengaruh glukomanan pada tepung porang sebagai agen anti-obesitas terhadap berat badan dan asupan makan pada tikus yang diinduksi oleh diet tinggi lemak. Metode: Penelitian dilakukan di Laboratorium Farmakologi, Fakultas Kedokteran, Universitas Brawijaya. Penelitian ini menggunakan desain penelitian true eksperimental. Hewan dibagi menjadi enam kelompok, kelompok normal; normal + tepung porang; kelompok obesitas; kelompok obesitas + tepung porang $100 \mathrm{mg} / \mathrm{kg} \mathrm{BB}$; kelompok obesitas + tepung porang $200 \mathrm{mg} / \mathrm{kg} \mathrm{BB}$; kelompok obesitas + tepung porang $400 \mathrm{mg} / \mathrm{kg}$ BB. Hasil: Berdasarkan hasil uji One Way Annova, terdapat perbedaan yang signifikan $(\mathrm{p}=0,000)$ pada berat badan setelah pemberian tepung porang pada semua kelompok. Berdasarkan uji Kruskal Wallis, terdapat perbedaan asupan makan pada berbagai kelompok $(\mathrm{p}=0,000)$. Simpulan: Dapat disimpulkan bahwa tepung porang dapat menurunkan berat badan dan asupan makan pada tikus yang diinduksi oleh diet tinggi lemak.
\end{abstract}

KATA KUNCI: berat badan; nafsu makan; glukomanan; tepung porang; obesitas

\section{PENDAHULUAN}

Berdasarkan data dari World Health Organization, studi epidemiologik menunjukkan bahwa prevalensi obesitas secara global mengalami peningkatan yaitu lebih dari satu milyar orang dewasa terkena penyakit kronik ini. Oleh karena itu, strategi untuk mengontrol berat badan telah banyak diteliti saat ini (1). Di bidang ilmu pangan, penelitian mengenai obesitas difokuskan pada pencarian kandungan dalam bahan pangan yang

Korespondensi: Choirun Nissa, Program Studi Ilmu Gizi, STIKes Widya Cipta Husada Malang, Jl. Jenderal Sudirman (Sidotopo) No. 11, Kepanjen, Malang, Jawa Timur 65163, Indonesia, Telp 0341-395996, Fax 0341-395999, e-mail: nissachoirun88@gmail.com 
mampu mempengaruhi kebutuhan atau konsumsi energi dalam tubuh.

Obesitas sangat berhubungan erat dengan patologi penyakit seperti penyakit jantung, diabetes tipe 2 , hipertensi, dan beberapa kanker. Obesitas terjadi akibat berlebihnya simpanan trigliserida di jaringan adiposa dan disebabkan oleh ketidakseimbangan antara intake energi dibandingkan kebutuhannya (2). Berbagai terapi untuk mencegah maupun mengobati obesitas diantaranya dengan bedah, obat-obatan, dan modifikasi gaya hidup yaitu diet dan olahraga (3). Salah satu terapi diet adalah dengan melalui asupan diet tinggi serat, terutama serat larut air (4).

Amorphillus muelleri blume atau porang merupakan umbi yang diketahui mengandung glukomanan. Glukomanan merupakan polisakarida non pati larut air yang dikenal sebagai serat larut air. Glukomanan mempunyai kemampuan untuk menurunkan kadar kolesterol darah dan kadar gula darah, menurunkan berat badan, dan mempengaruhi aktivitas intestinal dan fungsi sistem imun (5). Tepung porang ini telah digunakan secara tradisional di Jepang sebagai makanan dan obat (6).

Penurunan berat badan merupakan tanda klinis yang paling utama digunakan sebagai target dalam manajemen obesitas. Penurunan berat badan ini akan tampak sebagai manifestasi klinis dari manajemen obesitas. Pada pemberian agen anti-obesitas, mekanisme penurunan berat badan dapat melalui penekanan ekspresi gen-gen lipogenik dan mempengaruhi sinyal kenyang di otak sehingga menurunkan asupan makan. Berdasarkan kesenjangan fakta dan teori yang dikemukakan tersebut maka peneliti ingin mengetahui pengaruh pemberian Amorphillus muelleri blume sebagai agen anti-obesitas terhadap berat badan dan nafsu makan pada tikus dengan induksi diet tinggi lemak.

\section{BAHAN DAN METODE}

Penelitian ini menggunakan desain true experimental. Sampel dalam penelitian ini adalah tikus Rattus norvegicus strain wistar, jantan, usia \pm 8 minggu, berat badan awal \pm 150 gram yang didapatkan dari Laboratorium Farmakologi Fakultas Kedokteran Universitas Brawijaya Malang dan mendapat persetujuan dari Komisi Etik Penelitian Kesehatan Fakultas Kedokteran Universitas Brawijaya dengan No. 025/EC/ KEPK/01/2015. Penelitian dilakukan di Laboratorium Farmakologi Fakultas Kedokteran Universitas Brawijaya Malang pada bulan Oktober 2014 - Maret 2015.

Sampel ditentukan secara random. Sampel ditempatkan pada lingkungan laboratorium dengan siklus gelap 12 jam dan terang 12 jam. Semua hewan coba mempunyai kemudahan akses mendapatkan air dan pakan selama proses penelitian. Sebanyak 36 ekor tikus dibagi ke dalam 6 kelompok, masing-masing 6 ekor tikus yaitu kelompok normal (N), normal porang (NP), kelompok obesitas (O), kelompok obesitas + porang $100 \mathrm{mg} / \mathrm{kg} \mathrm{BB}$ (OP1), kelompok obesitas + porang $200 \mathrm{mg} / \mathrm{kg} \mathrm{BB}(\mathrm{OP} 2)$, kelompok obesitas + porang $400 \mathrm{mg} / \mathrm{kg} \mathrm{BB}$ (OP3).

Sebelum diinduksi obesitas, hewan coba diaklimatisasi terlebih dahulu selama 1 minggu. Induksi obesitas dilakukan melalui pemberian diet tinggi lemak. Komposisi diet tinggi lemak yang digunakan dalam penelitian ini adalah pakan ayam standar/ParS ditambah tepung terigu, minyak kelapa, kuning telur bebek, lemak kambing, dan minyak babi. Sebanyak 24 tikus kelompok obesitas diberi diet tinggi lemak selama 8 minggu sedangkan 12 tikus kelompok normal diberi pakan normal. Pemberian diet dilakukan secara ad libitum.

Umbi porang didapatkan dari Pusat Penelitian dan Pengembangan Porang Indonesia (P4I). Umbi porang dibersihkan, dikupas, dan dicuci dengan air bersih. Umbi diiris dengan ketebalan $\pm 5 \mathrm{~cm}$ dan dijemur di bawah terik matahari hingga benar-benar kering ( \pm 5 hari). Porang harus benar-benar kering untuk menghindari timbulnya jamur. Irisan porang yang telah kering dimasukkan dalam disc mill (mesin penepung) dan dihaluskan lebih lanjut menggunakan ball mill (mesin penepung). Tepung porang difraksinasi (pemisahan senyawa berdasarkan berat jenis). Pada tahap ini, kalsium oksalat dan zat pengotor yang lain akan dibuang dengan cara dihembuskan. Selanjutnya, dilakukan pencucian dengan etanol. Tahap ini bertujuan untuk meminimalisir kandungan kalsium oksalat yang dapat menyebabkan gatal pada kulit dan mengendap di ginjal serta merusak hati, juga meminimalisir zat-zat pengotor pada tepung porang sehingga yang tersisa sebagian besar adalah glukomanan. Setiap 100 gram tepung porang mengandung abu $6 \%$; air $0 \%$; pati $24 \%$; 
protein 5\%; serat kasar 11,6\%; glukomanan 41\%; dan kalsium oksalat $6 \%$.

Setelah induksi obesitas, pada tikus kelompok normal porang dan obesitas porang diberi tepung porang sebanyak 100 mg/kg BB; 200 mg/kg BB; dan 400 mg/kg BB selama 8 minggu berikutnya. Tepung porang diberikan per oral dengan bantuan sonde yang dilarutkan dengan aquades dingin terlebih dahulu. Setiap hari dilakukan monitoring terhadap sisa pakan sedangkan monitoring berat badan dilakukan satu minggu sekali. Pengukuran tersebut menggunakan timbangan digital.

Seluruh data disajikan dalam bentuk rerata dan standar deviasi. Sebelum dilakukan uji bivariat, terlebih dahulu dilakukan uji normalitas dan homogenitas data. Data hasil pengukuran berat badan dan sisa pakan dianalisis statistik dengan One Way Anova dan dilanjutkan dengan uji Post Hoc Tuckey. Uji statistik dilakukan pada derajat kepercayaan 95\% dan perbedaan ini bermakna apabila nilai $\mathrm{p}$ kurang dari 0,05 .

\section{HASIL}

\section{Pengaruh diet tinggi lemak terhadap berat badan pada berbagai kelompok}

Berdasarkan uji One Way Annova, berat badan awal tikus pada semua kelompok tidak memiliki perbedaan yang signifikan $(p=0,357)$. Selain itu berdasarkan uji homonegitas, berat badan awal tikus termasuk homogen $(\mathrm{p}=0,961)$. Gambar 1 menunjukkan bahwa berdasarkan uji Kruskal-Wallis, pemberian diet tinggi lemak terhadap berat badan pada berbagai kelompok menunjukkan perbedaan yang signifikan ( $p=0,000)$. Berdasarkan uji Mann-Whitney, tampak bahwa rerata berat badan pada kelompok tikus normal (NO dan NP1) menunjukkan perbedaan yang berarti dengan kelompok tikus yang diinduksi obesitas $(\mathrm{O}$, OP1, OP2, dan OP3). Hal tersebut membuktikan bahwa berat badan pada tikus yang diberi diet tinggi lemak secara bermakna lebih tinggi dibandingkan pada tikus yang mendapatkan diet normal.

\section{Pengaruh tepung porang terhadap berat badan pada berbagai kelompok}

Gambar 2 menunjukkan bahwa berdasarkan uji One Way Annova, didapatkan perbedaan yang signifikan

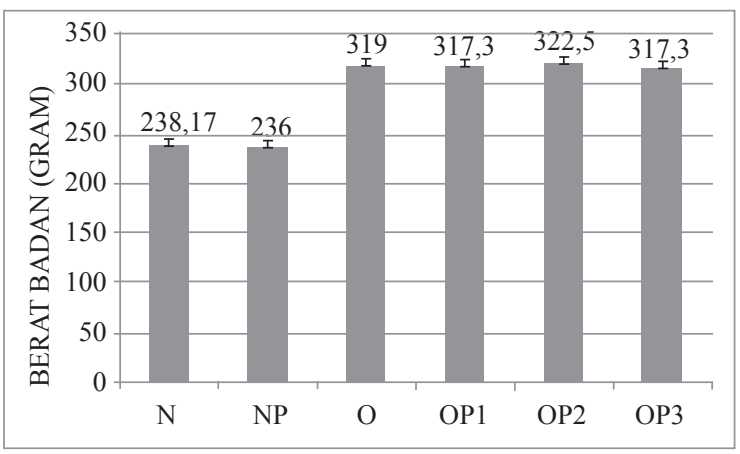

Gambar 1. Rerata berat badan setelah induksi obesitas pada berbagai kelompok

Keterangan: Rata-rata berat badan setelah induksi obesitas pada kelompok perlakuan NO; NP; O; OP1; OP2; OP3 adalah $238,17 \pm 5,6 ; 236 \pm 5,76 ; 319 \pm 4,77 ; 317,3 \pm 5,43 ; 322,5$ $\pm 4,64 ; 317,3 \pm 4,46$ dengan $\mathrm{p}=0,000$

$(p=0,000)$ rata-rata berat badan setelah pemberian tepung porang pada semua kelompok perlakuan. Rata-rata berat badan tertinggi terdapat pada kelompok kontrol positif/ obese (O) yaitu sebesar $379 \pm 4,77$ sedangkan rata-rata berat badan terendah didapatkan pada kelompok obesitas porang 3 (OP3) yaitu sebesar 237,3 $\pm 4,46$. Namun, berdasarkan uji Post Hoc Tuckey didapatkan rata-rata berat badan setelah pemberian porang pada kelompok normal (NO) berbeda signifikan terhadap kelompok normal porang (NP). Selain itu, rata-rata berat badan setelah pemberian porang pada kelompok obesitas (O) berbeda signifikan terhadap kelompok obesitas porang 1, 2 maupun 3 (OP1, OP2, OP3). Sementara itu, rata-rata berat badan setelah pemberian tepung porang pada kelompok obesitas porang 2 (OP2) tidak berbeda signifikan terhadap kelompok normal (NO). Hal tersebut menunjukkan bahwa kelompok yang diberi tepung porang memiliki berat badan yang lebih rendah daripada kelompok yang tidak diberi tepung porang baik pada kondisi normal maupun obesitas. Pemberian tepung porang pada dosis $200 \mathrm{mg} / \mathrm{kg}$ BB dapat menurunkan berat badan sama dengan kondisi normal.

\section{Pengaruh tepung porang terhadap asupan makan pada berbagai kelompok}

Gambar 3 menunjukkan bahwa berdasarkan uji One Way Annova didapatkan bahwa terdapat perbedaan asupan makan pada berbagai kelompok perlakuan $(\mathrm{p}=0,000)$. Berdasarkan uji Post Hoc Tukey, rerata sisa 


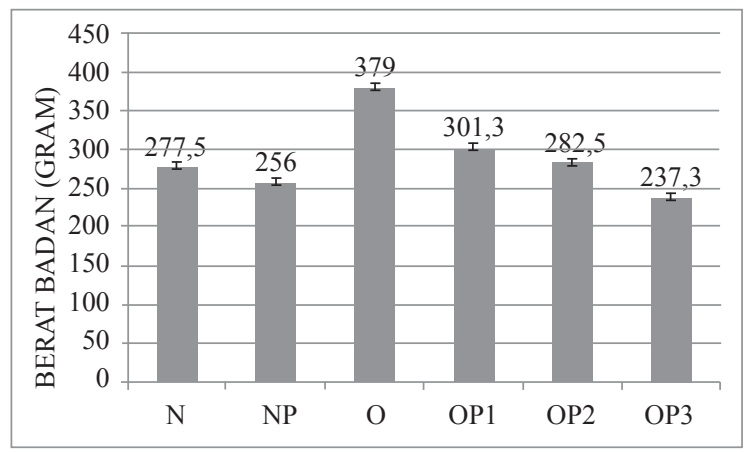

Gambar 2. Rerata berat badan setelah pemberian tepung porang pada berbagai kelompok

Keterangan: Rata-rata berat badan setelah pemberian tepung porang pada kelompok perlakuan NO; NP; O; OP1; OP2; OP3 adalah $277,5 \pm 5,43 ; 256 \pm 5,76 ; 379 \pm 4,77 ; 301,3 \pm 5,43$; $282,5 \pm 4,64 ; 237,3 \pm 4,46$ dengan $\mathrm{p}=0,000$

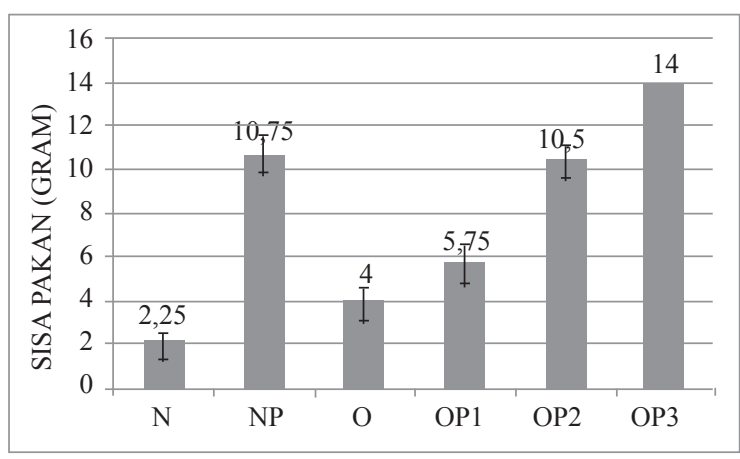

Gambar 3. Rerata asupan makan setelah pemberian tepung porang pada berbagai kelompok

Keterangan: Rata-rata asupan makan setelah pemberian tepung porang pada kelompok perlakuan NO; NP; O; OP1; OP2; OP3 adalah $37,75 \pm 0,27 ; 29,25 \pm 0,82 ; 36 \pm 0,55 ; 34,25 \pm$ 0,$82 ; 29,5 \pm 0,55 ; 26 \pm 1,09$ dengan $\mathrm{p}=0,000$

pakan pada kelompok NP berbeda signifikan dengan kelompok NO, selain itu rerata sisa pakan pada kelompok OP1, OP2, dan OP3 berbeda signifikan dengan kelompok O. Hal ini menunjukkan bahwa pemberian tepung porang dapat menurunkan asupan pakan pada tikus normal maupun obesitas.

\section{BAHASAN}

Hasil penelitian menunjukkan bahwa pada akhir induksi obesitas, kelompok yang diberi diet tinggi lemak memiliki berat badan yang lebih tinggi daripada kelompok yang diberi diet normal. Hal ini didukung oleh penelitian sebelumnya yang dilakukan di Perancis pada tahun 2008 bahwa induksi diet tinggi lemak pada tikus mampu meningkatkan berat badan melalui modulasi mikrobiota usus sehingga terjadi peningkatan permeabilitas dan kemampuan absorpsi usus (7). Peningkatan asam lemak bebas yang terakumulasi di jaringan akan meningkatkan akumulasi acyl-CoA rantai panjang dan metabolitnya diantaranya diacylglycerol (DAG), triacylglycerol (TAG), dan seramid di intrasel. Akumulasi seramid memicu defosforilasi protein kinase B/Akt. Defosforilasi $\mathrm{PKB} / \mathrm{Akt}$ memicu transportasi glukosa ke jaringan melalui peningkatan aktivitas glucose transporter-4 (GLUT-4) sehingga terjadi peningkatan glikogenesis (8). Defosforilasi PKB/Akt juga menghambat lipolisis dan glukoneogenensis di jaringan. Peningkatan uptake glukosa ke jaringan dan glikogenesis serta downregulasi lipolisis dan glukoneogenesis menyebabkan peningkatan massa tubuh. Dengan demikian diet tinggi lemak dapat digunakan sebagai induksi obesitas karena dapat meningkatkan berat badan secara signifikan.

Hasil penelitian ini menunjukkan bahwa pada kelompok normal maupun kelompok obesitas yang diberi tepung porang yang mengandung glukomanan terbukti dapat menurunkan berat badan dibanding kelompok yang tidak diberi tepung porang. Penelitian yang dilakukan di Amerika Serikat pada tahun 2007 dan 2008 membuktikan bahwa glukomanan mampu menurunkan berat badan pada subjek yang menderita obesitas $(9,10)$. Penurunan berat badan ini diduga karena sifat fisik glukomanan yang dapat membentuk gel dan meningkatkan viskositas saluran cerna sehingga menurunkan absorpsi makanan oleh usus. Penelitian lain di Spanyol pada tahun 2010 menyatakan bahwa konsumsi serat meningkatkan viskositas melalui pembentukan lapisan gel dan bersifat impermiabel di saluran gastrointestinal (11). Pembentukan gel oleh serat mampu menghalangi kontak makanan dengan dinding saluran cerna (12).

Penurunan berat badan juga disebabkan adanya mekanisme molekuler glukomanan dalam memicu lipolisis di jaringan. Glukomanan merupakan serat larut air yang tidak tercerna namun difermentasi di ileum dan kolon menjadi bentuk short chain fatty acid (SCFA) (13). SCFA mengaktivasi free fatty acid receptor-2 (FFAR2) sehingga memicu disosiasi dan mengaktifkan protein Gi/o yang menghambat adenilat siklase dan menurunkan produksi cyclic adenosine monophospate 
(cAMP) dari ATP sehingga menurunkan aktivitas protein kinase A (PKA). Penurunan aktivitas PKA akan memicu defosforilasi dan deaktivasi hormone sensitive lipase (HSL) di jaringan adiposa. Aktivasi FFAR2 oleh SCFA juga menekan sinyal insulin di jaringan adiposa dengan menghambat fosforilasi Akt sehingga menghambat penyimpanan lipid di jaringan adiposa dan memicu metabolisme lipid dan glukosa di jaringan lain (14).

Hasil penelitian ini menunjukkan bahwa kelompok normal yang diberi tepung porang dosis $200 \mathrm{mg} / \mathrm{kg}$ berat badan (BB) dan kelompok obesitas yang diberi tepung porang dengan dosis $400 \mathrm{mg} / \mathrm{kg}$ BB mengalami penurunan berat badan di bawah berat badan kelompok normal. Dengan demikian, konsumsi serat glukomanan harus sesuai dengan kebutuhan, apabila terlalu banyak dikhawatirkan dapat menyebabkan penurunan berat badan yang berlebihan. Oleh karena itu, untuk menghindari penurunan berat badan yang berlebihan, pada individu normal disarankan mengkonsumsi serat sesuai dengan kebutuhannya sedangkan pada individu obesitas boleh dilakukan penambahan konsumsi serat sedikit di atas kebutuhan. Namun, diperlukan studi lebih lanjut mengenai hal tersebut.

Penurunan berat badan pada kelompok yang diberi tepung porang juga disebabkan oleh penurunan asupan makan. Hal ini ditunjukkan dari hasil penelitian bahwa asupan makan pada kelompok yang diberi tepung porang lebih rendah. Asupan makan yang lebih rendah disebabkan tepung porang membentuk gel dan meningkatkan viskositas di saluran cerna serta memperlambat gerak peristaltik yang menurunkan kontak makanan dengan saluran cerna sehingga memicu sinyal kenyang di otak. Serat meningkatkan viskositas dan mampu menyerap air berlebih sehingga memperlambat gerak gastrointestinal dan memicu sinyal kenyang dan memperlambat pengosongan lambung (15-18).

\section{SIMPULAN DAN SARAN}

Glukomanan pada tepung porang (Amorphillus muelleri blume) dapat menurunkan berat badan dan nafsu makan pada tikus yang diinduksi dengan diet tinggi lemak. Dosis yang paling efektif dalam menurunkan berat badan pada tikus obesitas yang diinduksi diet tiggi lemak adalah $200 \mathrm{mg} / \mathrm{kg}$ BB. Dibutuhkan studi lebih lanjut mengenai konsumsi serat glukomanan di atas kebutuhan pada individu normal, hubungannya dengan penurunan berat badan yang berlebih.

\section{UCAPAN TERIMA KASIH}

Penelitian ini mendapatkan bantuan dana dari Hibah Penelitian Desentralisasi Dosen Pemula Dirjen Dikti Tahun Anggaran 2015. Peneliti juga berterima kasih pada Pusat Penelitian dan Pengembangan Porang Indonesia, Universitas Brawijaya atas dukungan berupa pemberian tepung porang.

\section{Pernyataan konflik kepentingan}

Penulis menyatakan tidak ada konflik kepentingan dengan pihak-pihak yang terkait dalam penelitian ini.

\section{RUJUKAN}

1. Blundell JE. A psychobiological approach to appetite and weight control. In eating disorders and obesity: a comprehensive textbook. New York: Guilford Press; 2002.

2. Hill JO, John CP. Environmental contributions to the obesity epidemic. Science 1998;(280):1371-4.

3. Lyon, Michael R., Reichert, Ronald G. The effect of a novel viscous polysaccharide along with lifestyle changes on short-term weight loss and associated risk factors in overweight and obese adults: an observational retrospective clinical program analysis. Altern Med Rev 2010;15(1):68-75.

4. Queenan KM, Stewart ML, Smith KN. Concentrated oat beta-glucan, a fermentable fiber, loers serum cholesterol in hypercholesterolemic adults in a randomized controlled trial. Nutr J 2007;(6):6-14.

5. Chotigamas T, Sirisansaneeyakul S, Sripaoraya S, Gateprasert M, Vanichsriratana W. Process development for Konjac (Amorphophallus oncophyllus) glucomannan production using cell suspension culture technique. Proceedings TRF -master Research Congress IV (Science and Technology); 2010 March 30-31; Pattaya, Cholburi.

6. Wootton NA, Luker-Brown, Westcott R.J. The extraction of a glucomannan polysaccharide from konjac corms (elephant yam, Amorphophallus rivierii). J Sci Food Agric 1993;61:429-33.

7. Cani PD, Bibiloni R, Knauf C, Waget A, Neyrinck $\mathrm{AM}$, Burcelin R. Changes in gut microbiota control: 
metabolic endotoxemia-induced inflammation in highfat diet-induced obesity and diabetes in mice. Diabetes 2008;57(6):1470-81.

8. King MW. Diabetes Mellitus. [series online] 2013 [cited 2014 Jun 12]. Available from: URL: http.// thebiomedicalbiochemistrypage.org.

9. Wood RJ, Fernandez ML, Sharman MJ, Silvestre R, Greene CM, Volek JS. Effects of a carbohydrate-restricted diet with and without supplemental soluble fiber on plasma lowdensity lipoprotein cholesterol and other clinical markers of cardiovascular risk. Metabolism 2007;56(1):5867.

10. Birketvedt GS, Shimshi M, Erling T, Florholmen J. Experiences with three different fiber supplements in weight reduction. Med Sci Monit 2005;11(1):PI5-8.

11. Johnson IT, Gee JM. Effect of gel-forming gums on the intestinal unstirred layer and sugar transport in vitro. Gut 1981;22(5):398-403.

12. Elsenhans B, Zenker D, Caspary WF. Guarran effect on rat intestinal absorption. Gastroenterology 1984; 86(4):64553.
13. Scheppach W. Effects of short chain fatty acids on gut morphology and function. Gut 1994;35(1):S35-8.

14. Besten den G, Eunen van K, AK Groen, K Venema, DJ Reijngoud, BM Bakker. The role of short-chain fatty acids in the interplay between diet, gut microbiota, and host energy metabolism. J Lipid Res 2013;54(9):2325-40.

15. de Graaf C, Bloom WA, Smeets PA, Stafleu A, Hendriks HF. Biomarkers of satietion and satiety. Am J Clin Nutr 2004;79(6):946-61.

16. Benini L, Castellani G, Brighenti F, Heaton W, Brentegani MT, Casiraghi MC. Gastric emptying of a solid meal is accelerated by the removal of dietary fibre naturally present on food. Gut 1995;36(6):825-30.

17. Bergmann JF, Chassany O, Petit A, Triki R, Caulin C, Segrestaa JM. Correlation between echographic gastric emptying and appetite: influence of psyllium. Gut 1992;33(8):1042-3.

18. Marciani L, Gowland PA, Spiller RC, Manoj P, Moore RJ, Fillery-Travis AJ. Gastric response to increased meal viscosity assessed by echo-planar magnetic resonance imaging in humans. J Nutr 2000;130(1):122-7. 